\title{
FoMO and JoMO Phenomenon of Active Millennial Instagram Users at 2020 in Jakarta
}

\author{
Jiren Grashyla Aurel ${ }^{1}$ Sinta Paramita ${ }^{1 *}$ \\ ${ }^{1}$ Faculty of Communication, Universitas Tarumanagara, West Jakarta, DKI Jakarta 11440, Indonesia \\ *Corresponding author. Email: sintap@fikom.untar.ac.id
}

\begin{abstract}
Face-to-face interpersonal communication is the most effective of all communication types. Due to the Covid19 outbreak in 2020, Indonesians have been forced to communicate online. The outbreak was followed up by Large-Scale Social Restrictions (PSBB). The increasing use of Instagram due to the communication crisis give possible symptoms of Fear of Missing Out (FoMO). In addition, they may also experience Joy of Missing Out (JoMO) caused by the long-time disconnection of face-to-face communication. This research aims to determine the symptoms of FoMO and JoMO among active millennial Instagram users at 2020 PSBB in Jakarta and analyze the causes with Fundamental Interpersonal Relations Orientation (FIRO), namely the three basic needs of interpersonal communication; inclusion, control, and affection. This research uses the FIRO Theory and approaches in the phenomenological method. The results are; millennial Instagram users do have symptoms of FoMO and JoMO during PSBB; from the three needs of interpersonal communication, what causes individuals to experience FoMO and JoMO is affection; FoMO with over personal affection is caused by fear of losing relationships and affection; JoMO with the same affection (over personal) focuses on maintaining relationships in real life, and JoMO with interpersonal affection is caused by the distrust in interactions.
\end{abstract}

\section{Keywords: Interpersonal communication, fear of missing out, the joy of missing out}

\section{INTRODUCTION}

There is no one who does not communicate or can avoid it, we often hear this term with "One Cannot Not Communicate" by Griffin. [1] Although communication is inherent in humans, Effendy said that no one is completely effective in communicating. [2], because according to DeVito, in every communication process, various barriers always occur. Barriers are all things that can distort the message that being conveyed. [3] From all communication types, face-to-face interpersonal communication is considered to be the most effective because when face-toface communication takes place, the contact that occurs can form the meaning of the non-verbal communication response, so as to minimize the occurrence of communication barriers. [4] It used to be very easy to communicate face-to-face every day, but due to the Covid19 outbreak in 2020, Indonesians have been forced to communicate online. The outbreak was followed up by Large-Scale Social Restrictions (PSBB). [5] People are using Instagram as a means of communication during quarantine thus causing Instagram usage to increase by $40 \%$. [6] The increasing use of Instagram due to the communication crisis give possible symptoms of Fear of Missing Out (FoMO). According to Przybylski, everyone can represent themselves and communicate with each other on social media. Activities that are shared can be seen by everyone. These interactions form bonds that have an impact on individuals who actively socialize on social media, resulting in a desire to be connected with other people's activities continuously. This situation is called FoMO, which is a social anxiety syndrome which has the characteristic of always wanting to be connected and know what people are doing, and is generally dominated by millennials. [7] The digital company, OptinMonster, explains statistics throughout 2020 that as many as $40 \%$ of millennials use their money excessively and even go into debt to maintain interpersonal relationships with their friends. In addition, $39 \%$ of the millennial generation is envy, $30 \%$ is jealous, and $21 \%$ is sad and disappointed because their friends' activities are more interesting than what they do. [8]

Apart from the possibility of having FoMO symptoms, millennials may also experience symptoms of Joy of Missing Out (JoMO). According to Phelan, JoMO is a way of life to feel more relaxed and have no problem finding out late information. Humans need technology in their lives, but not as much as they think and JoMO is how to balance it. [9] This possibility is based on an interpersonal communication crisis due to the long disconnection in faceto-face communication. During the quarantine, many people spend time on themselves, make individuals selfreflect, and spend a lot of time with their families. [10] It was also found that apart from the victims of Covid-19, PSBB made people more grateful for small things and could enjoy life. Even before the existence of the PSBB in Jakarta, 
research of more than 2,200 people across the UK in 2019 has shown that $78 \%$ of millennials experience JoMO and feel happier to stay at home. $41 \%$ of them admit to saving more money and think that quality is more important than quantity when it comes to communication. [11] From the problems that have been described, then this research concludes the issue to be "How are the symptoms of FoMO and JoMO among active millennial Instagram users at 2020 PSBB in Jakarta and the causes with Fundamental Interpersonal Relations Orientation Theory (FIRO)?”.

\subsection{Related Work}

\subsubsection{FoMO among Adolescents in Samarinda City by Akbar et al.}

Research by Akbar et al. [7] in 2018 entitled "FoMO among Adolescents in Samarinda City" explained that the causes of people with FoMO symptoms are the unfulfilled "relatedness needs" that they are unable to be close to other individuals and the unfulfilled "self needs", that they are unable to fulfill their life desires. Akbar explained that social media is the main cause of people becoming FoMO, and the effects of FoMO are not caring about their surroundings and themselves, messed up their sleeping and eating time, feeling dissatisfied for what they have, and unable to enjoy the real life. The research by Akbar has a differences with this study. This study discusses the FoMO phenomenon in the urgency of the Covid-19 pandemic which deals with communication crisis

\subsubsection{From FoMO to JoMO by Kiding}

The 2019 study entitled "From Fomo to Jomo: Overcoming Fear of Missing Out and Fostering Resilience against Dependence on the Digital World" by Kiding and Matulessy explained that JoMO behavior greatly influences the subject's ability to reside from FoMO behavior. JoMO's behavior is said to have a positive impact on the resilient ability of adolescents preventing FoMO. JoMO individuals are stated to be able to limit the use of social media. [9] The differences between the research by Kiding and Matulessy with this study are, this research discusses the JoMO phenomenon in a more actual problem and analyzes its causes in the context of interpersonal communication during the Covid-19 pandemic.

\subsubsection{FIRO of Student at a Coffee Shop by Erdiyanti}

Research by Erdiyanti entitled "Interpersonal Communication of UIN Sunan Ampel Surabaya Activists Student at a Coffee Shop in Review of William Schutz Fundamental Interpersonal Relations Orientation", in 2017, explained that the students at a coffee shop carried out various types of communication, such as open communication. They put their trust in interpersonal communication by exchanging ideas and supporting each other thus causing affection. Both Erdiyanti's and this study are look at the needs of interpersonal communication, one of the differences is the location. Erdiyanti's research do not have any urgency or big problems unlike this study which discuss communication crisis due to Covid-19 pandemic.

\subsection{Our Contribution}

This research is expanding knowledge about the symptoms of FoMO and JoMO in millennials. This study contributes to becoming a new reference for further research related to any forms of communication crisis. Practically speaking, this study also reminding millennials to improve the balance between communicating on social media and real-life. This research is also adding new insights about communication during the 2020 PSBB in Jakarta. In addition to answering the research objectives, this paper presents some improvements from the previous researches. This study complements the shortcomings of the research by Akbar et al. [7] Who recommends other researchers to do research on FoMO in different locations and subjects, then this study follow the recommendations by do the research in Jakarta in the urgency of the Covid-19 pandemic related to the communication crisis. This study also strengthens the results of Kiding and Matulessy's research [9] on JoMO behavior which gives a person the ability to be resilient to FoMO. Then, this study also complements Erdiyanti's [9] lack of familiarity with the research subject by observing informants more deeply so as to strengthen the research results related to the analysis of FIRO theory in interpersonal communication.

\subsection{Paper Structure}

This paper is structured as follows. Section 1 (Introduction) introduces the preliminaries by explaining the issues by data and the urgency of the communication crisis in millennials during the 2020 PSBB in Jakarta, discusses related studies by summarizing the existing work, and discuss the differences with this study by explaining the actuality of the communication crisis due to the Covid-19 pandemic. Sub section "Our Contribution" explains the author contributions towards the advancement of communication studies by adding something new to the knowledge. Section 2 (Background) Explains all concepts about this paper that the reader needs to understand by introduces FoMO, JoMO, and FIRO Theory based on references from existing work. Section 3 (Methods) describes the process of qualitative research that is looking for, analyzing, and managing the phenomenon to figure out the social interactions directly in the field. Section 4 (Finding and Discussion) identifies and discusses data to answers the objectives of this research, contextualizes the findings of FoMO, JoMO, and FIRO within previous research and theory, explains unexpected results that differ this study from previous research. Finally, Section 5 concludes the study and presents suggestions for future research. 


\section{BACKGROUND}

\subsection{Fear of Missing Out (FoMO)}

FoMO was first created by a writer named Patrick J. McGinnis in 2004, through his opinion entitled "McGinnis' Two FO's: Social Theory." The paper was published by Harvard Business School in The Harbus magazine and placed in the opinion section. Then, in 2012, FoMO was further researched by JW Intelligence, the study explained that FoMO is a feeling of anxiety and fear of being left behind when a friend does and feels something that is more fun or better than what he currently does and has. People who FoMO also feel worried if they miss information on the current trend. [7] The British Institute of Health, the Royal Society of Public Health, deepen the research in 2017 and stated that people with FoMO feel inferior, humiliated, and depressed because of the fear of being judged by people, and about $40 \%$ of social media users have FoMO. In 2015, the largest organization of psychologists in Australia, the Australian Psychological Society, released the results of a survey on Stress and Wellbeing in Australia, the survey stated that $50 \%$ of adolescents have FoMO and dominated by people aged 18-35 years old. [12]

\subsection{Joy of Missing Out (JoMO)}

The name Joy of Missing Out was first coined in 2012 by Anil Dash on his personal blog, Dash is a writer and CEO of Glitch. JoMO became popular in 2014, when a writer, digital expert and podcast host named Christina Crook promoted the JoMO lifestyle by writing the book The Joy of Missing Out. Crook revealed that implementing JoMO is a conscious effort to disconnect from the world of the internet in order to get offline moments in real life. [13] The JoMO lifestyle has a slower rhythm, focuses on relationships in real life, is able to say no, gives a special space by detaching self from technology, giving self-time to feel all emotions, [9] and being able to enjoy their own time without bothering to think about what other people are doing. [14]

\subsection{Fundamental Interpersonal Relations Orientation Theory (FIRO)}

FIRO is a sub theory of interpersonal communication which is commonly referred to as the theory of interpersonal needs. It was coined by William Schutz in 1958. The assumption of the theory is humans are social creatures so that in their lives they always need other humans. Humans need three basic interpersonal needs in their life to be in a relationship with other humans. [14] According to William Schutz, those three needs are as follows; 1.) Inclusion (participation), is a need based on the awareness of individuals who want to get satisfaction when interacting by contributing to the group; 2.) Control (Control), is a need based on the awareness of individuals who want to get satisfaction when interacting with controlling, leading, influencing, and being dominant in determining decisions; 3.) Affection (affection) is the need to have and maintain a relationship in order to get affection and love.

\subsection{FIRO as a Theory to Analyze the Causes of FoMO and JoMO}

According to Przybylski, people who have FoMO are caused by low satisfaction and needs in life, as well as bad moods in real life. [7] Meanwhile, JoMO is the opposite of FoMO, said Fuller, JoMO is caused by satisfaction with the life that's being lived right now. [14] These causes have the keyword "satisfaction of needs" so they are relevant to the FIRO theory which explains that human interaction can be formed because of three interpersonal needs, these are inclusion, control and affection. [14] These three needs will be used as an analysis of the causes of FoMO and JoMO in this paper.

\section{METHODS}

This study is qualitative research that is looking for, analyzing, and managing the phenomenon to figure out the social interactions directly in the field. [16] Researcher collects and analyzes data using the phenomenological method, which aims to interpret social actions in individuals which are then interpreted and reconstructed into derivative meanings. [17] The subject in this study are millennials who live in Jakarta. This research uses non-random sampling method to determine the subject, and uses purposeful sampling technique, that is selecting subjects based on the characteristics that are in accordance with the research objectives. [18] The subject criteria according to the research objectives are; millennials whose born between 1980 - 2000; [19] active Instagram users; have been or are in the 2020 PSBB in Jakarta; have friends or a playmate. The object of this research is the millennials active Instagram users who have been or are in the 2020 PSBB in Jakarta, who may have FoMO and JoMO. There are six informants. Referring to the Dukkes statement, the number of research subjects in phenomenological research is 3-10 people in one phenomenon. [20] Data consists of primary and secondary data. Primary data is obtained from interviews and observations of informants, while secondary data is obtained from documentation and literature studies in the form of photos of the duration of Instagram usage, Instagram profiles, and supporting images, as well as journals and books. In processing and analyzing the data, the researcher conducted reduction, presentation, and verification. The reduction begins with interviews, transcripts, then takes the core of the information by open coding and classifies the symptoms into 9 sub-titles. Then, the researcher presented the data by looking for the similarity of the 9 sub (section) systematically to answer the research objectives. Furthermore, the researcher verified the data by re-observing the data with the informants' activities on Instagram and giving conclusions. After verification, the researcher interpreted the data by comparing the findings 
with previous research written in the theoretical framework and other credible sources.

\section{FINDINGS AND DISCUSSIONS}

\subsection{The Symptoms of FoMO on Millennial Active Instagram Users at PSBB 2020 in Jakarta}

\subsubsection{Low Life Satisfaction and Bad Mood}

Millennials who have FoMO at PSBB admit that they are very dissatisfied with their lives because they can't communicate face-to-face with their friends, feel uneasy, annoyed, and are tired of communicating online from home. Besides, individuals who are FoMO also have a bad mood at the time of PSBB. The results of this study are in line with the journal which explains that one of the people who have FoMO is caused by a low feeling of satisfaction and need in life, as well as a bad mood in real life. [7] Individuals from the results of this study consider online communication to be ineffective, individuals get upset with themselves when they see their friends on Instagram, look more productive, and remain calm while undergoing PSBB. "Get upset" means feelings of inferiority. The results of this study are in line with research conducted by the Royal Society of Public Health, which studied in 2017, that people with FoMO feel inferior. [7] Then, inefficient online communication, which irritates individuals, is also in line with what Ibid stated that from all communication types, face-to-face interpersonal communication is considered to be the most effective because when face-to-face communication takes place, the contact that occurs can form the meaning of the non-verbal communication response, to minimize the occurrence of communication barriers [4]

\subsubsection{Checking Friends' Instagram Activity Continually}

People with FoMO continue to check their friends' activities on Instagram with the reason they want to know what new activities are being carried out in life changes during PSBB. Continuously checking on friends' activities impacts FoMO with self-comparing, anxiety, and jealousy because their friends seem more productive and having fun with others without them. The results of this research are in line with JWTIntelligence's, the study said that people with FoMO feel anxious and afraid when their friends do things that are more fun than what they do or have. [17] Przybylski's research also shows similarities, that stated people with FoMO have negative effects, as like low self-identity and self-image, jealousy, feelings of inadequacy, and feel marginalized. [7]

\subsubsection{Negative Responses While Being Offline from Instagram}

Individuals with FoMO feel lost when they off from Instagram during PSBB and are afraid of missing new information about their friends and what just happened. Additionally, individuals will return to check Instagram again at least before bed. This statement is in accordance with previous research by Dossey in Putri, entitled "FOMO, Digital Dementia and Our Dangerous Experiment" which explained that people with FoMO surf the internet before sleeping, waking up, eating, and driving so they don't miss information. [17] People who experience FoMO feel afraid that their communication will not be connected when the individual doesn't know what trends their friends are talking about and immediately find out right away so they can communicate with their friends on the same topic. This statement is in line with previous research, that states people with FoMO are worried if they don't know the current trend or their friends ask questions about their nescience of the latest information [7] They use Instagram approximately 78 hours a day. These results are corroborated by a study entitled "Social Networks Users: Fear of Missing Out in Preservice Teachers" which states that the total duration of FoMO's social media usage is 5-7 hours. [17]

\subsubsection{Unable to Say No}

People with FoMO show that they are unable to refuse when their friends ask them to go out during PSBB because they rarely meet and are afraid of missing moments. This statement is very much in accordance with the research of Przyblylski et al. Which stated the definition of FoMO, that is, the fear of losing the precious moments of another individual or group where the individual can't be present. [7]

\subsection{The Symptoms of JoMO on Millennial Active Instagram Users at PSBB 2020 in Jakarta}

\subsubsection{Good Satisfaction in Life and Good Mood}

Fuller said that JoMO is satisfied with the life that is being lived right now. [14] This statement is in line with the results of this study that, of all the impacts of PSBB, individuals feel very satisfied with their needs and have a good mood because their primary needs are fulfilled. Inefficient communication doesn't affect their life satisfaction and mood

\subsubsection{Focus on Real Life}

People with JoMO are not concerned with their friends' activities on Instagram and enjoy PSBB at home, they feel that they are don't need to know what their friends are doing even though they are close friends. When they see their 
friends experiencing something more enjoyable on Instagram, individuals admit their limitations and choose to return to their routine and carry out their responsibilities in life. However, people with JoMO don't cut off communication offhand but balance it out, they keep in touch on important days such as birthdays. The statement has a similarity to the definition of JoMO researched by Phelan in The New York Times article, that JoMO is about disconnecting, choosing not to join, and feeling okay wherever the person is. Humans in life need technology, but not as much as they think and JoMO is a way to balance it. [8]

\subsubsection{Positive Response When Quitting Instagram}

Individuals who are JoMO often take a break from Instagram because they think it's not essential. They are more productive in developing self-competence and are able to think more clearly. This has the same meaning as the definition of JoMO from the book entitled "The Joy of Missing Out", which is implementing JoMO as an effort that consciously made to disconnect from the internet in order to get moments in real life. [13] They don't care about being left behind and don't feel like they are missing anything. When his friend talks about the latest trends and they don't have any idea, the people with JoMO admit and don't try to find out. This statement is in line with the definition of JoMO in previous studies, stating a way of life that is more relaxed and doesn't matter if he is late in knowing information and news. [9] In addition, the accumulated usage of Instagram during PSBB by people with JoMO is 30 minutes - 2 hours a day, which is far below people with FoMO, which is 5-7 hours a day. [17]

\subsubsection{Being Able To Say No}

During the PSBB many people were still going outside, especially during the transition period. Even though the JoMO individuals are asked by their best friend, they dare to refuse and aren't afraid to miss the moment without their presence. This research is in line with Fuller's statement that JoMO individuals are able to refuse and give themselves time to feel all emotions. [9] JoMO individuals choose to allocate PSBB time for themselves at home by studying, working, relaxing, and playing games. This statement is in accordance with the research of the Harvard Study of Adult Development that people who live the JoMO lifestyle, experiencing solitude which is the deliberate act of being alone with constructive and positive involvement of selfinterest without feeling lonely. [21]

\subsection{Analysis of the Causes of FoMO and JoMO on Millennial Active Instagram Users in the 2020 PSBB with the Theory of Fundamental Interpersonal Relations Orientation (FIRO)}

This study shows that interpersonal needs cause individuals to experience FoMO and JoMO. Of the three basic needs for inclusion, control, and affection, the results of this study indicate that the causes of FoMO and JoMO are from affection needs. The type of affection that affects can be different and can be the same for each individual. There are individuals who are FoMO and JoMO on the other hand but have the same type of affection with different responses.

\subsubsection{The Causes of Fear of Missing Out}

Individuals who have FoMO have a high need for affection and are classified as over personal (excessive) affection type. They always have a close bond with other people in a dyadic way so that they can't be separated from their friends because their friends become half of the individuals who already know everything about them, can encourage, and always remind them. The need for intimate relationships excessively makes individuals unable to say no and afraid of missing moments, feeling anxious, and jealous when they are not present in their friend's activities. They also have a bad mood because unable to communicate face-to-face during PSBB. The need for interaction greatly affects individuals to check their friends' activities continually on Instagram. If they don't check it, individuals feel left out of information, are afraid of communication disconnection, and afraid of losing relationships. Overall, the individuals are afraid of losing the relationship and affection from their friends. The results of this study are in line with William Schutz's postulate regarding the need for affection in interpersonal communication, which is the need to have and maintain relationships in order to obtain affection and love. Affection is based on the need to be liked and to have close relationships with other people. People with over personal affection always have close relationships and close ties with other individuals. [14]

\subsubsection{The Causes of Joy of Missing Out}

Individuals who are JoMO have varied basic needs. There are JoMO with low affection needs and high needs as well. Even though people with FoMO and JoMO both have over personal affection (excessive), individuals who have a JoMO lifestyle have different responses. Either FoMO or JoMO, people with over personal affection always have strong bonds with others, maintain close relationships to be liked by people, want to receive positive feedback, and want to get comfort and compatibility in communicating. The difference is in the response that makes the individual JoMO and not FoMO. JoMO individuals with excessive affection maintain a close bond with real-life actions by doing things or producing work that makes their friends 
happy, even so, they don't feel compelled to check their friends' activities and don't mind if they miss any moments and focuses on maintaining the relationships in real life. The point is they don't depend on social media activities. The results of this study are reinforced by Aristotle's point of view, who has a similar view of the need for affection, that is, a friendship that exists is essential to achieve happiness and prioritize happiness as the final goal. [22]

Then, contrary to the previous statement, some people with JoMO are having under personal affection (deficiency). Individuals are less able to build intimacy with other people. Low levels of trust in friends consciously lead them to limit very-close relationships. Even though they have many friends, the individuals only have very close relationships with their families. Low affection needs affect their Instagram usage, they rarely upload something because they don't believe what friends say about their posts, besides that, they also don't care about their friends' activities and it doesn't matter if they miss any the moment. These individuals' characteristics show similar characteristics from the previous study, that stated under personal affection people always avoid close bonds and take the distance in maintaining relationships with other individuals. [14] It can be said, the individuals who place distrust in their interactions with friends affect the individuals to become a person with under personal affections, so they cannot have a close relationship and cause the individual to have JoMO symptoms. The results of this study are in line with the results of Beebe's research which states that, the relations in a relationship means to manage the relationship itself and interpersonal communication is a process of interaction that affects each other. [22]

\subsection{Differences and Similarities with The Results of Previous Researches}

\subsubsection{Fear of Missing Out}

The results of research by Akbar et al., 2018, entitled Fear of Missing Out (FoMO) in Adolescents in Samarinda City have several differences from this study. Akbar explained that the FoMO arises because individuals do not have a closeness to other people. [7] Meanwhile, the results of this research indicate the opposite that individuals who have FoMO are caused by excessive closeness to their friends and the PSBB makes individuals more afraid of losing the moment. However, there is also a similarity with Akbar's research which is another cause of being afraid of missing moments, that they can't fulfill their desires. In line with this research, while doing PSBB, People with FoMO can't fulfill their desires to communicate face-to-face and spend time outside with their friends, so those things are causing the symptoms of FoMO.

\subsubsection{Joy of Missing Out}

The results of this study (related to JoMO) have no difference from previous research in 2019 by Kiding and
Matulessy entitled "From FoMO to JoMO" [9]. However, both have similarities. Kiding's research reveals that the JoMO lifestyle can make individuals more flexible in using social media. [8]. All JoMO informants are active users of social media but can balance it well. Kiding's statements are in line with the results of this study that JoMO individuals still use social media at PSBB. It's just that the individuals have very good abilities to limit it and prefer to use their quarantine time to develop their potential.

\subsubsection{Fundamental Interpersonal Relations Orientation Theory}

The results of research by Erdiyanti in 2017 entitled "Interpersonal Communication of UIN Sunan Ampel Surabaya Activists Student at a Coffee Shop in Review of William Schutz Fundamental Interpersonal Relations Orientation" didn't show any differences (in the FIRO theory analysis) with this study, the difference lies in the location only. The similarities show that individuals entrust themselves to other individuals in interpersonal communication to exchange ideas and support each other so they increase their affection needs. [14] These results are similar to this study that states, the level of trust in interpersonal communication affects the type of affection in a person. Excessive affection is essentially trusting and maintaining a close bond with friends to get love and support. Meanwhile, affection deficiency puts distrust so that individuals have a low need for affection toward their friends. These two types of affection are the causes of FoMO and JoMO as described in the previous section.

\section{CONCLUSIONS}

Based on the findings and discussion of the research, it can be concluded that millennial Instagram users experience FoMO and JoMO while undergoing PSBB 2020 in Jakarta. They obtained more experience of JoMO than FoMO. Individuals who experience FoMO have low life life-needs satisfaction and a bad mood because they can't communicate face-to-face. They continually check their friends' activities on Instagram, compare themselves, feel anxious, and envious because their friends look more productive. They also feel lost when they are away from Instagram. People who have FoMO unable to say no when their friends ask them to go out while undergoing PSBB and afraid to miss the moment. Meanwhile, JoMO individuals have the satisfaction of life and have a good mood because they think the important thing is they still can fulfill their primary needs. Inefficient communication doesn't affect them that much, they don't care about what's happening and what their friends doing on Instagram. People with JoMO lifestyle enjoy PSBB at home without cut off the communication offhand, they don't care if they left behind, being able to say no and prefer to allocate time while PSBB to develop self-potential. The basic needs of interpersonal communication cause individuals to experience FoMO and JoMO. From the three needs these are inclusion, control, and affection, the only cause is from the need for affection. 
The types of affection are different and also the same in each individual. Some individuals are FoMO and the others are JoMO, but have the same type of affection with different responses. Millennials who have FoMO are caused by the over personal affection type, and those who experience JoMO are caused by under personal and over personal affection types. FoMO with over personal affection is caused by fear of losing relationships and affection from their friends. Their needs of interactions cause people with FoMO to continually check their friends' activities on Instagram. Meanwhile, JoMO individuals with the same type of affection (over personal) show different responses, they tend to focus on maintaining relationships in real life by doing things that make their friends happy, so they don't depend on social media activities. Besides, JoMO with under personal affection is caused by the interaction of individuals who place distrust on interactions with their friends, which makes them unable to have a close relationship with anyone except their families and causes JoMO symptoms. Through this research, we provide academic and practical advice. For the academy, this paper recommends further researchers to focus on affection need in interpersonal communication in analyzing the causes of FoMO and JoMO because, from the three interpersonal needs of FIRO, what causes individuals to become FoMO and JoMO is only the affection need. Then, for the practice, we suggest communication practitioners in universities to give compulsory seminars for students about the symptoms of FoMO and its threats and how to become more JoMO.

\section{ACKNOWLEDGMENT}

This work was supported by Institutions of Professional Development Foundation (LPP) of Tarumanagara University, Indonesia.

\section{REFERENCES}

[1] Mubaroka, "Communication between advisors and assisted residents in the coaching process at the Class IIA women's penitentiary, Semarang Anzilna," Jurnal Interaksi Online, vol. 6, no. 3, 2018. DOI: https:// ejournal3.undip.ac.id/index.php/interaksi-online/article/ view/20878/19568

[2] S. Purnamasari, "The relationship between communication barriers and stress on parents who have deaf children in special public schools (SDLBN), Pekanbaru.," Riau: Islam Negeri Sultan Syarif Kasim Unviersity, 2018. DOI: http://repository.uin-suska.ac.id/ 13786/

[3] T. Chandra, "Communication barriers in tutoring activities between tutors and fifth grade elementary school children on the banks of the Kalimas River,
Surabaya," Jurnal E-Komunikasi, vol. 3, no. 2, pp. 1-12, 2015. DOI: https://media.neliti.com/media/publications/ 80637-ID-hambatan-komunikasi-dalam-aktivitas-bimb. pdf.

[4] C. Insyrah, The application of parental interpersonal communication in the formation of early childhood behavior in Palsabolas Village, Angkola Timur District, South Tapanuli Regency, Padangsimpuan: Fakultas Dakwah dan Ilmu Komunikasi Institusi Agama Islam Negeri Padangsimpuan, 2019.

[5] Detikcom Team, "Anies extended PSBB in Jakarta, June will be a transitional period," Detik.com, 4 June 2020. [Online]. Available: https://news.detik.com/berita/ d-5040091/anies-perpanjang-psbb-dki-jakarta-bulanjuni-jadi-masa-transisi. [Accessed 8 September 2020].

[6] "Digital access increases during the pandemic," Wantiknas, 2020. [Online]. Available: http://www. wantiknas.go.id/id/berita/akses-digital-meningkatselama-pademi. [Accessed 8 September 2020].

[7] e. a. Akbar, "The fear of missing out in adolescents in Samarinda City," Psikostudia, vol. 7, no. 2, pp. 38-47, 2018. DOI: http://e-journals.unmul.ac.id/index.php/ PSIKO/article/view/2404/pdf\#.

[8] A. Hott, "25+ Powerful FOMO Statistics to Skyrocket Sales (2021)," OptinMonster, 6 January 2021. [Online]. Available: https://optinmonster.com/fomostatistics/ [Accessed 15 January 2021].

[9] S. Kiding, "From fomo to jomo: overcoming fear of loss (fomo) and fostering resilience to dependence on the digital world," PSISULA: Prosiding Berkala Psikologi, vol. 1, pp. 173-182, 2019. DOI: http://jurnal.unissula. ac.id/index.php/psisula/article/view/7702 .

[10] R. Indriani, "Behind the disaster there is a lesson from corona covid-19, this is what the residents said," Suara.com, 4 April 2020. [Online]. Available: https:// www.suara.com/lifestyle/2020/04/04/095754/di-balikmusibah-ada-hikmah-dari-corona-covid-19-ini-diacurhatan-warga?page=all. [Accessed 5 September 2020].

[11] K. O’Malley, "Jomo replaces fomo as $78 \%$ of millennials would rather stay at home," Independent, 29 January 2019. [Online]. Available: https://www. independent.co.uk/life-style/jomo-fomo-millennialsnetflix-spotify-subscriptions-marie-kondo-a8752216. html. [Accessed 15 January 2021].

[12] H. Marano, "What Is Solitude?," Psychology Today, 13 December 2019. [Online]. Available: https://www. 
psychologytoday.com/us/articles/200307/what-issolitude. [Accessed 6 September 2020].

[13] C. Crook, The Joy Of Missing Out: Finding Balance In A Wired World, Canada: New Society Publishers, 2015.

[14] S. Barr, "Five signs you've swapped fomo for jomo," Independent, 30 January 2019. [Online]. Available: https://www.independent.co.uk/life-style/ jomo-fomo-fear-joy-missing-out-millennials-netflixspotify-friends-socialise-cinema-a8753626.html. [Accessed 6 September 2020].

[15] N. Erdiyanti, Interpersonal communication of activist students at UIN Sunan Ampel Surabaya in a review of fundamental theory of interpersonal relations orientation William Schutz, Surabaya: Thesis of Islam Negeri Sunan Ampel University, 2017. DOI: http:// digilib.uinsby.ac.id/19431/

[16] Sugiyono, Metode penelitian kuantitatif dan kualitatif r\&d, Bandung: CV Afabeta, 2018.

[17] N. A. Putri, The relationship between the intensity of social media use and the degree of loneliness among adolescents in school "X" Bandung, Bandung: Thesis of Maranatha Christian University, 2018.

[18] Eric, Viral marketing through digital content (a case study of the Netflix street food series, the lupis episode, Mbah Satinem), Jakarta: Thesis of Faculty of Communication, Tarumanagara University., 2020.

[19] C. V. \&. D. A. Candraningrum, "E-wom by millennial against the @makansampaikenyang account as a culinary recommendation provider," Jurnal Prologia, vol. 2, no. 2, pp. 270-277, 2018.

[20] D. M. Anshori, The psychological well-being of single women in middle adulthood, Surabaya: Thesis of Faculty of Psychology, Islam Negeri Sunan Ampel: Surabaya University, 2015.

[21] Marano, "What is solitude?," Psychology Today, 13 December 2016. [Online]. Available: https://www. psychologytoday.com/us/articles/200307/what-issolitude. [Accessed 6 September 2020].

[22] D. Prasanti, "Firo theory analysis in the relation of friendship as the study of interpersonal communication," Jurnal Komunikasi, vol. 9, no. 2, pp. 186-189, 2018. 